\title{
ZOOPLANKTON BIOMASS OF RESERVOIRS IN DIFFERENT TROPHIC CONDITIONS IN THE STATE OF SÃO PAULO, BRAZIL
}

\author{
SENDACZ, S. ${ }^{1}$, CALEFFI, S. ${ }^{2}$ and SANTOS-SOARES, J. ${ }^{3}$ \\ ${ }^{1}$ Instituto de Pesca, Secretaria de Agricultura e Abastecimento do Estado de São Paulo \\ ${ }^{2}$ Petróleo Brasileiro SA, Refinaria de Capuava, \\ Av. Alberto Soares Sampaio, 2122 A, CEP 09380-904, Mauá, São Paulo, SP \\ ${ }^{3}$ Fundação Parque Zoológico \\ Correspondence to: Suzana Sendacz, Instituto de Pesca, \\ Secretaria de Agricultura e Abastecimento do Estado de São Paulo, \\ Av. Francisco Matarazzo, 455, CEP 05001-900, São Paulo, SP, Brazil, \\ e-mail: sendacz@pesca.sp.gov.br \\ Received April 23, 2004 - Accepted July 7, 2004 - Distributed February 28, 2006 \\ (With 4 figures)
}

\begin{abstract}
This paper reports on a study involving an estimate of the biomass of rotifers, cladocerans, and cyclopoid and calanoid copepods found in reservoirs in different trophic conditions, comparing and relating numerical density data and pointing out differences between the dry and rainy seasons. In terms of numerical densities, both reservoirs were dominated by rotifers, although cladocerans represented a higher biomass in the oligotrophic environment in both seasons. In the eutrophic environment, higher biomass values were found for cyclopoids during the dry season and for cladocerans during the rainy one. Different biomass patterns were observed relating to both the trophic conditions and the rainy and dry seasons.
\end{abstract}

Keywords: biomass, zooplankton, trophic state, Alto Tietê Basin.

\section{RESUMO}

\section{Biomassa de organismos zooplanctônicos em represas de diferentes condições tróficas do Estado de São Paulo, Brasil}

Este trabalho descreve um estudo sobre a determinação dos valores de biomassa de rotíferos, cladóceros, copépodos calanóides e ciclopóides em represas de diferentes estados tróficos, com o objetivo de comparar e relacionar com dados de densidades numéricas, considerando os períodos chuvoso quente e estiagem frio. Verificou-se que, embora rotíferos tenham dominado numericamente em ambas as represas, em termos de biomassa os cladóceros predominaram no ambiente oligotrófico, em ambos os períodos considerados. No ambiente eutrófico, copépodos ciclopóides predominaram no período estiagem frio, e cladóceros, no chuvoso quente, evidenciando padrões diferenciados de biomassa tanto em relação às condições tróficas quanto aos períodos chuvoso e seco.

Palavras-chave: biomassa, zooplâncton, estado trófico, Bacia do Alto Tietê.

\section{INTRODUCTION}

The species of the zooplankton community display a wide array of sizes, so numerical population densities do not always provide useful information (Matsumura-Tundisi et al., 1989), making comparative studies of tropical and temperate reservoirs or different hydrographic basins and trophic states difficult.
Several authors, among them Dumont et al. (1975), Bottrell et al. (1976) and Culver et al. (1985), have estimated the biomass of temperate lakes and reservoirs. As for tropical and subtropical water bodies, Burgis (1974), Saint-Jean (1983) and Hart (1987), among others, conducted studies on African lakes and reservoirs. In Brazil, studies on the zooplankton biomass of eutrophic and oligotrophic 
reservoirs have been undertaken by MatsumuraTundisi \& Tundisi (1986), Matsumura-Tundisi et al. (1989), Esteves \& Sendacz (1988), Melão (1997), Melão \& Rocha (2000) and Wisniewski (1998). Saunders \& Lewis (1988) and Vásquez \& Rey (1992) determined the zooplankton biomass of lakes in Venezuela.

The zooplankton communities of most tropical and subtropical lakes and reservoirs are dominated by rotifers, regardless of the trophic state, but due to their small size and weight, they often contribute little to the biomass.

Zooplankton biomass estimated from weight-length relationships reported in the literature should be avoided, since temperature, food quality and quantity, species genotype, seasons and differences in the physical conditions of habitats, among other factors, can lead to changes in the carbon content of each species (Dumont et al., 1975; Vijverberg, 1989).

The sites studied here, Ponte Nova $\left(23^{\circ} 33^{\prime} \mathrm{S}, 45^{\circ} 50^{\prime} \mathrm{W}\right)$ and Guarapiranga $\left(23^{\circ}\right.$ $\left.43^{\prime} \mathrm{S}, 46^{\circ} 32^{\prime} \mathrm{W}\right)$ reservoirs, are located in the Alto Tietê Hydrographic Basin (Fig. 1). The two reservoirs are part of the water supply system of metropolitan São Paulo, Brazil, and were among the 17 reservoirs studied in 1979 by researchers of the Instituto de Pesca (Institute of Fishery) as part of the project "Tipologia de reservatórios do Estado de São Paulo" (Typology of the reservoirs of the state of São Paulo), when abiotic and biotic variables were obtained (Maier \& Takino, 1985a; 1985b; Sendacz et al., 1985; Xavier et al., 1985; Esteves \& Sendacz, 1988). At that time, the Ponte Nova reservoir displayed a low trophic state compared with other studied reservoirs.

Ever since the 1930s, several researchers have been concerned about the eutrophication and pollution process that the Guarapiranga reservoir has suffered. Eutrophication has rendered treatment of the water supply increasingly difficult and expensive, and the use of copper sulfate to control algae blooms has been intensified since 1990. Aspects of the zooplankton community of the Guarapiranga reservoir, such as composition and seasonal fluctuation of numerical densities, have been studied by Sendacz \& Kubo (1982, 1999), Sendacz et al. (1985), Domingos (1993), and Caleffi $(1994,2000)$.
The estimates of the zooplankton biomass in the present study will provide data to relate and compare different trophic states of the reservoirs under study, and to identify differences relating to the dry and rainy seasons.

\section{METHODS}

A sampling station was set up in each reservoir, in the limnetic zone near the dam (Fig. 1). During this study, it was found that the application of the algicide copper sulfate - a practice usually adopted in Guarapiranga to control algae blooms - had been suspended.

Water samples were collected at depths corresponding to the surface, $50 \%, 25 \%, 10 \%$ and $1 \%$ of light penetration, and at the bottom, using a 5-L Van Dorn bottle. The Modified Trophic State Index (MTSI) proposed by Toledo Jr et al. (1983) was calculated based on transparency (Secchi disk), chlorophyll a (Marker et al., 1980) and total phosphorus (Valderrana, 1981).

Zooplankton samplings were collected using plankton nets of 40 and $60 \mu \mathrm{m}$ mesh for rotifers and crustaceans, respectively, through vertical hauls of the entire water column. Organisms were anesthetized by $\mathrm{CO}_{2}$ (soda water) and preserved in $4 \%$ formalin.

A quantitative analysis of zooplankton was made by counting subsamples, using a Sedgwick-Rafter chamber for rotifers, and a counting chamber for crustaceans. Quadrants of a $7.5 \mathrm{~cm}$ Petri dish or whole samples were counted when the numerical densities were low.

The weights of the most abundant rotifers were determined indirectly, based on biovolumes calculated from formulas proposed by RuttnerKolisko (1977). Using a micrometric eyepiece, measurements were taken of at least 20 individuals of each rotifer species to determine their biovolumes. Dry weights were calculated considering $10 \%$ of the fresh weight estimated through biovolumes (Doohan, apud Bottrell et al., 1976).

The methodology proposed by Wetzel \& Likens (1991) was adopted for the microcrustaceans: 10 to 50 individuals of the most abundant species were isolated according to their different developmental phases (Copepoda: nauplii, copepodids, males, females, ovigerous females; 


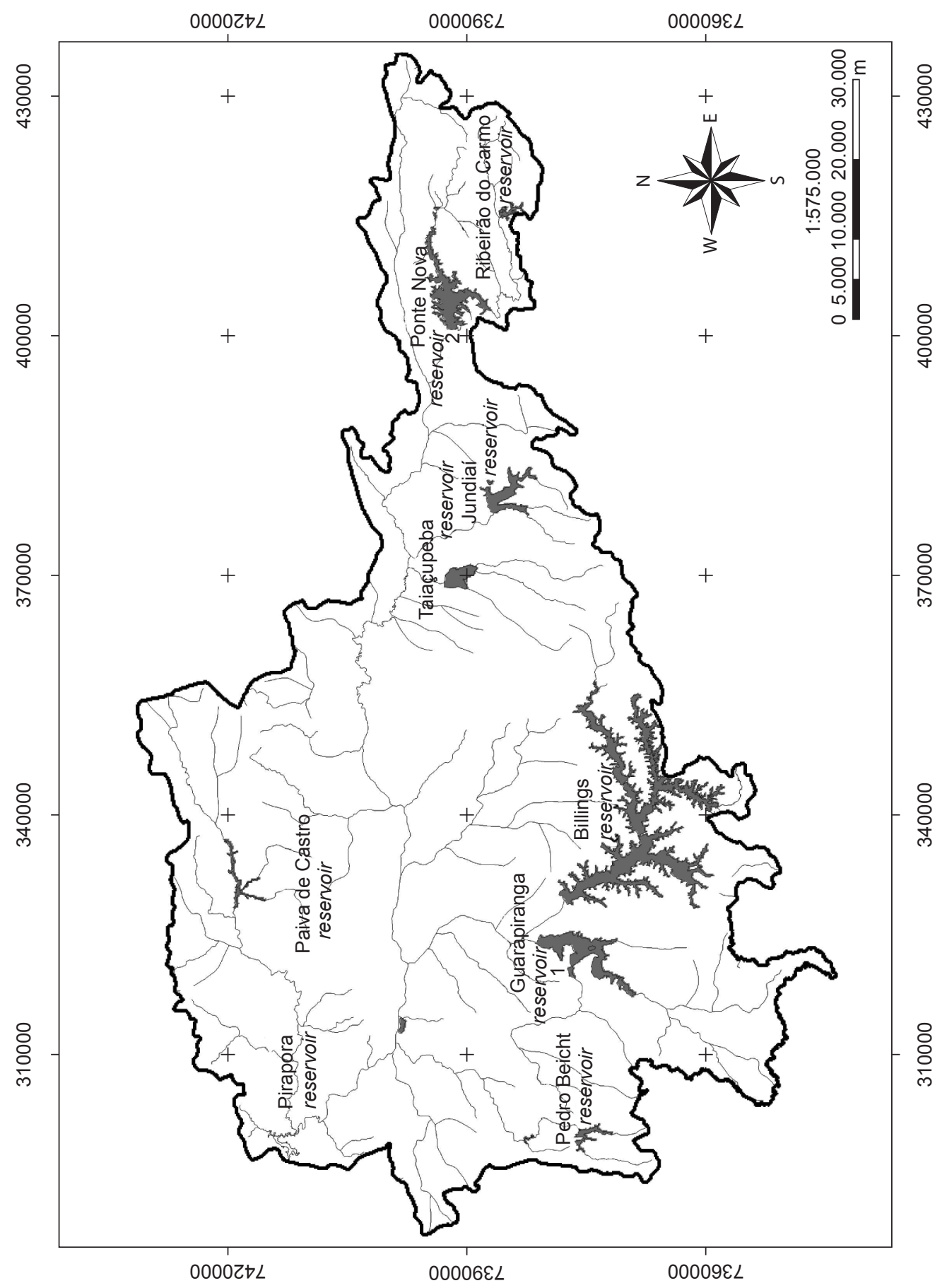

Fig. 1 - Alto Tietê Hydrographic Basin: 1) Guarapiranga reservoir; and 2) Ponte Nova reservoir. 
Cladocera: young, adult females, ovigerous females). The organisms were rinsed three times in distilled water to remove the fixation material (formalin) and then dried at $60{ }^{\circ} \mathrm{C}$ for $24 \mathrm{~h}$ in small preweighed aluminum foil boats. To cool them, the animals were transferred to a desiccation chamber for $1 \mathrm{~h}$, and then weighed on a Mettler UMT microbalance.

\section{RESULTS}

Monthly rainfall (in $\mathrm{mm}$ ), considering the cold-dry (Apr to Sep 2001) and the warm-rainy
(Oct 2001 to Mar 2002) seasons, are shown in Fig. 2. The mean rainfall in the dry season was $44.2 \mathrm{~mm}$ in Ponte Nova and $40.6 \mathrm{~mm}$ in Guarapiranga. The mean rainfall values in the rainy season were higher in Ponte Nova $(227.6 \mathrm{~mm})$ than in Guarapiranga (183.1 mm).

Table 1 shows water transparency, maximum depths, chlorophyll $a$ and total phosphorus concentrations, and MTSI (Toledo Jr. et al., 1983). With the exception of transparency and depths, the values were higher for the Guarapiranga reservoir, with slight differences found between the dry and rainy seasons.

\section{Ponte Nova}

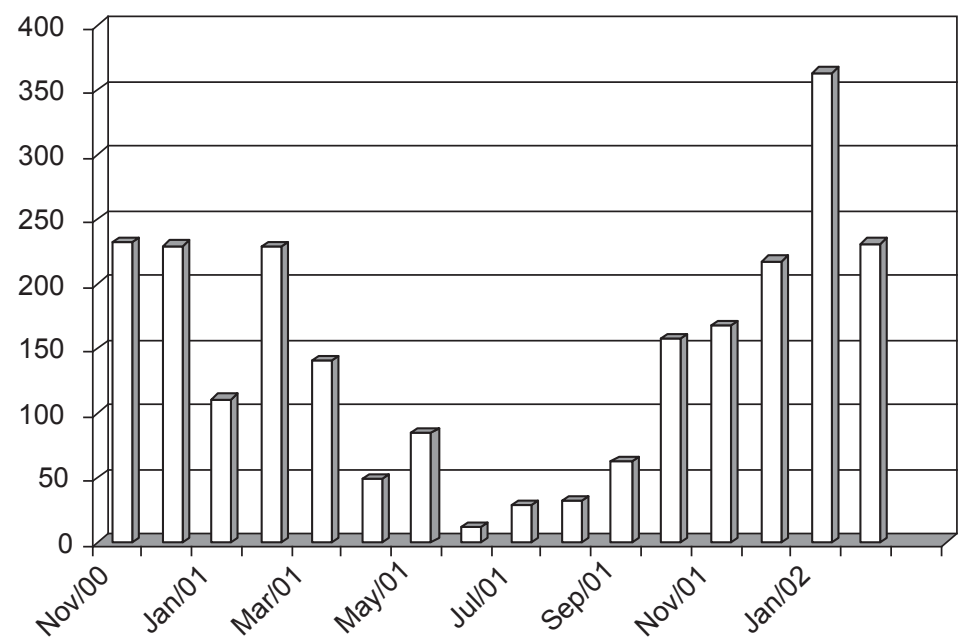

Guarapiranga

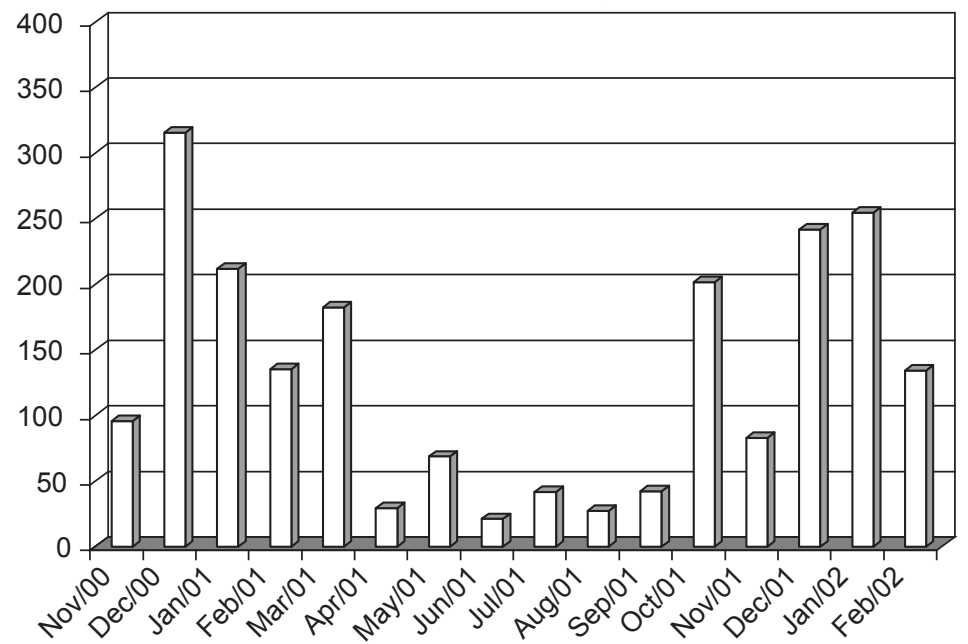

Fig. 2 - Total precipitation (mm) of Ponte Nova and Guarapiranga reservoirs from November 2000 to February 2002. 
TABLE 1

Depth (m), transparency (m), chlorophyll (ug.L $\mathrm{L}^{-1}$ ), total phosphorus (ug.L $\mathrm{L}^{-1}$ ), and Modified Trophic State Index (MTSI) for Ponte Nova and Guarapiranga reservoirs, in Aug 2001 and Feb 2002.

\begin{tabular}{|l|c|c|c|c|}
\hline \multirow{2}{*}{ Ponte Nova } & \multicolumn{2}{|c|}{ Aug 2001 } & \multicolumn{2}{c|}{ Feb 2002 } \\
\cline { 2 - 5 } & & MTSI & & MTSI \\
\hline Depth $(\mathrm{m})$ & 12.7 & & 12.0 & \\
\hline Transparency (m) & 2.6 & 36.98 & 1.9 & 41.51 \\
\hline Chlorophyll (ug. - $\left.^{-1}\right)$ & 5.89 & 48.35 & 5.26 & 47.21 \\
\hline Total phosphorus (ug.L $\left.{ }^{-1}\right)$ & 12.2 & 32.81 & 14.2 & 35.00 \\
\hline MTSI & - & 42.68 & - & 41.19 \\
\hline
\end{tabular}

\begin{tabular}{|l|c|c|c|c|}
\hline \multirow{2}{*}{ Guarapiranga } & \multicolumn{2}{|c|}{ Aug 2001 } & \multicolumn{2}{c|}{ Feb 2002 } \\
\cline { 2 - 5 } & & MTSI & & MTSI \\
\hline Depth (m) & 5.0 & - & 7.0 & - \\
\hline Transparency (m) & 0.9 & 52.29 & 0.8 & 53.99 \\
\hline Chlorophyll (ug. - $\left.^{-1}\right)$ & 31.18 & 65.06 & 25.94 & 63.21 \\
\hline Total phosphorus (ug. L $\left.^{-1}\right)$ & 64.00 & 56.72 & 53.47 & 54.13 \\
\hline MTSI & - & 59.17 & - & 57.73 \\
\hline
\end{tabular}

Differences were also observed in the composition of the reservoirs' zooplankton communities (Tables 2 and 3). Collotheca ornata, Conochilus dossuarius, Conochilus unicornis, Kellicottia bostoniensis, Keratella cochlearis, Polyarthra vulgaris and Trichocerca pusilla were common to both reservoirs. Ascomorpha saltans, Brachionus mirus, Collotheca mutabilis, Filinia longiseta limnetica, Ptygura libera and Trichocerca $s p$ were restricted to Ponte Nova, and Asplanchna sp, Brachionus calyciflorus, B. havanaensis, Filinia opoliensis, Synchaeta oblonga and Trichocerca capucina to Guarapiranga.

Cyclopoids were represented in Ponte Nova by Tropocyclops prasinus and sporadically by Mesocyclops longisetus and M. meridianus. In Guarapiranga, the cyclopoid species found were Thermocyclops decipiens, $T$. inversus and Tropocyclops prasinus. Odontodiaptomus paulistanus was the only calanoid found in Ponte Nova, while Notodiaptomus deitersi, N. iheringi, Notodiaptomus henseni and, sporadically, N. cearensis occurred in Guarapiranga (Tables 2 and 3).

Several congeneric species of cladocerans were observed, such as Bosmina longirostris, $B$. hagmanni and B. tubicen, Ceriodaphnia cornuta rigaudi and C. silvestrii, Daphnia ambigua and D. gessneri, Moina minuta and M. micrura in Ponte Nova, and Ceriodaphnia cornuta cornuta and C. silvestrii, Daphnia ambigua and D. gessneri in Guarapiranga (Tables 2 and 3).

During the cold dry season (August 2001), the total zooplankton densities in Guarapiranga were about 10 times higher $\left(677,501\right.$ organisms. $\left.\mathrm{m}^{-3}\right)$ than in Ponte Nova $\left(69,064\right.$ organisms. $\left.\mathrm{m}^{-3}\right)$, while during the warm rainy season (February 2002), these differences were less important (Fig. 3). Considering both seasons, in Ponte Nova rotifers represented $86.2 \%$ of the total zooplankton, cyclopoids $2 \%$, calanoids $0.4 \%$, and cladocerans $21 \%$. In Guarapiranga, rotifers represented $74.5 \%$ of the total zooplankton, cyclopoids $28 \%$, calanoids $0.1 \%$, and cladocerans $6 \%$.

During the dry season Polyarthra vulgaris, Ptygura libera, Conochilus unicornis and Collotheca ornata predominated in Ponte Nova, and P. vulgaris and Synchaeta oblonga in Guarapiranga. In the rainy season $C$. ornata and Kellicottia bostoniensis predominated in Ponte Nova, while Keratella cochlearis tecta, $P$. vulgaris cf. longiremis and Filinia opoliensis predominated in Guarapiranga.

Though present in both reservoirs, Tropocyclops prasinus represented $10 \%$ of 
TABLE 2

Ponte Nova reservoir: numerical densities (ind.m $\left.{ }^{-3}\right)$, individual dry weights $(\mu \mathrm{gDW})$ and biomass $\left(\mu \mathrm{gDW} . \mathrm{m}^{-3}\right)$ of rotifers, cyclopoids, calanoids and cladocerans in Aug 2001 and Feb 2002 ( $\partial$, males; + , females; + ov, ovigerous females; y, young).

\begin{tabular}{|c|c|c|c|c|c|c|c|}
\hline \multirow{2}{*}{\multicolumn{2}{|c|}{ Rotifera }} & \multicolumn{3}{|c|}{ Aug 2001} & \multicolumn{3}{|c|}{ Feb 2002} \\
\hline & & \multirow{2}{*}{$\begin{array}{c}\text { ind.m } \\
1162 \\
\end{array}$} & \multirow{2}{*}{$\begin{array}{r}\mu \mathbf{g D W} \\
0.010\end{array}$} & \multirow{2}{*}{$\frac{\mu \mathrm{gDW} \mathbf{m}^{-3}}{11.62}$} & \multirow{2}{*}{$\begin{array}{c}\text { ind.m }{ }^{-3} \\
-\end{array}$} & \multirow{2}{*}{$\begin{array}{c}\mu \mathrm{gDW} \\
-\end{array}$} & \multirow{2}{*}{\begin{tabular}{|c|}
$\mu g \mathbf{W} \cdot m^{-3}$ \\
-
\end{tabular}} \\
\hline Ascomorpha saltans & & & & & & & \\
\hline Brachionus mirus typicus & & 232 & - & - & 5645 & 0.0102 & 57.55 \\
\hline Collotheca mutabilis & & 1511 & 0.065 & 98.66 & 2880 & 0.0260 & 74.86 \\
\hline Collotheca ornata & & 10227 & 0.024 & 249.55 & 77882 & 0.0046 & 357.70 \\
\hline Conochilus dossuarius & & 232 & - & - & 691 & - & - \\
\hline Conochilus unicornis & & 11390 & 0.015 & 174.26 & 29263 & 0.0111 & 323.91 \\
\hline Filinia longiseta limnetica & & - & - & - & 3226 & 0.0357 & 115.16 \\
\hline Hexarthra intermedia & & - & - & - & 13364 & 0.0252 & 336.24 \\
\hline Horaella thomassoni & & - & - & - & 230 & - & - \\
\hline Kellicottia bostoniensis & & 116 & - & - & 40899 & 0.0042 & 170.92 \\
\hline Keratella americana & & - & - & - & 115 & - & - \\
\hline Keratella cochlearis & & 2441 & 0.001 & 3.17 & 20507 & 0.0012 & 24.85 \\
\hline Polyarthra vulgaris & & 11971 & 0.060 & 720.63 & 9447 & 0.0558 & 527.06 \\
\hline Ptygura libera & & 11971 & 0.018 & 209.49 & 230 & - & - \\
\hline Trichocerca pusilla & & 232 & - & - & 115 & - & - \\
\hline Trichocerca sp & & 465 & - & - & - & - & - \\
\hline Bdelloidea & & 1162 & - & - & - & - & - \\
\hline Subtotal & & 53111 & - & 1467.38 & 204495 & - & 1988.24 \\
\hline \multicolumn{8}{|l|}{\begin{tabular}{|c} 
Copepoda Cyclopoida \\
\end{tabular}} \\
\hline Nauplii & & 883 & 0.55 & 487.29 & 309 & 0.68 & 209.96 \\
\hline Copepodids & & 288 & 0.76 & 217.96 & 194 & 0.76 & 147.10 \\
\hline \multirow[t]{3}{*}{ Mesocyplops meridianus } & $\hat{0}$ & 9 & - & - & - & - & - \\
\hline & q & 79 & 8.77 & 692.83 & - & - & - \\
\hline & qov & 1 & - & - & - & - & - \\
\hline \multirow[t]{3}{*}{ Tropocyclops prasinus } & o & 14 & - & - & 9 & - & - \\
\hline & q & 56 & 2.10 & 117.60 & 2 & - & - \\
\hline & qov & 65 & 2.18 & 141.89 & 2 & - & - \\
\hline Subtotal & & 1395 & 14.36 & 1657.57 & 516 & - & 357.06 \\
\hline \multicolumn{8}{|l|}{ Copepoda Calanoida } \\
\hline Nauplii & & 79 & 0.77 & 60.67 & 25 & - & - \\
\hline Copepodids & & 135 & 3.83 & 517.67 & 16 & - & - \\
\hline \multirow[t]{3}{*}{ Odontodiaptomus paulistanus } & $\hat{0}$ & 28 & 9.54 & 267.17 & 2 & - & - \\
\hline & $q$ & 26 & 13.78 & 358.35 & 21 & - & - \\
\hline & Pov & 3 & - & - & 2 & - & - \\
\hline Subtotal & & 271 & - & 1203.87 & 67 & - & - \\
\hline \multicolumn{8}{|l|}{ Cladocera } \\
\hline \multirow[t]{3}{*}{ Bosmina longirostris } & $\mathrm{y}$ & 10227 & 0.33 & 3401.59 & 2212 & 0.44 & 973.29 \\
\hline & q & 1976 & 0.85 & 1686.19 & 747 & 0.73 & 544.99 \\
\hline & qov & 407 & 0.93 & 376.48 & 1161 & 0.94 & 1091.63 \\
\hline \multirow[t]{3}{*}{ Bosmina hagmanni } & $\mathrm{j}$ & - & - & - & 0 & - & - \\
\hline & q & - & - & - & 65 & - & - \\
\hline & $q_{\mathrm{ov}}$ & - & - & - & 28 & - & - \\
\hline
\end{tabular}


TABLE 2

Continued...

\begin{tabular}{|c|c|c|c|c|c|c|c|}
\hline \multirow[t]{3}{*}{ Bosmina tubicen } & $\mathrm{y}$ & - & - & - & 18 & - & - \\
\hline & $q$ & - & - & - & 120 & 3.58 & 428.95 \\
\hline & qov & - & - & - & 65 & - & - \\
\hline \multirow[t]{3}{*}{ Bosminopsis deitersi } & $\mathrm{y}$ & - & - & - & 9 & - & - \\
\hline & $q$ & - & - & - & 37 & - & - \\
\hline & qov & - & - & - & 46 & - & - \\
\hline \multirow[t]{3}{*}{ Ceriodaphnia cornuta rigaudi } & $\mathrm{y}$ & 260 & 2.17 & 564.20 & - & - & - \\
\hline & q & 232 & 2.71 & 628.72 & - & - & - \\
\hline & qov & 214 & 2.95 & 631.30 & - & - & - \\
\hline \multirow[t]{3}{*}{ Ceriodaphnia silvestrii } & $\mathrm{y}$ & 288 & 1.97 & 566.95 & 387 & 2.41 & 932.92 \\
\hline & $q$ & 390 & 2.99 & 1164.29 & 129 & 2.81 & 362.59 \\
\hline & qov & 205 & 3.78 & 774.52 & 55 & 4.20 & 232.26 \\
\hline \multirow[t]{3}{*}{ Diaphanosoma birgei } & $\mathrm{y}$ & - & - & - & 65 & - & - \\
\hline & q & - & - & - & 9 & - & - \\
\hline & qov & - & - & - & 28 & - & - \\
\hline \multirow[t]{3}{*}{ Daphnia ambigua } & $\mathrm{y}$ & 37 & - & - & 378 & 1.23 & 464.80 \\
\hline & $q$ & 62 & - & - & 55 & 4.46 & 246.64 \\
\hline & qov & 0 & - & - & 175 & 8.64 & 1513.02 \\
\hline \multirow[t]{3}{*}{ Daphnia gessneri } & $\mathrm{y}$ & 62 & - & - & 18 & - & - \\
\hline & q & 186 & - & - & 0 & - & - \\
\hline & qov & 0 & - & - & 18 & - & - \\
\hline \multirow[t]{3}{*}{ Moina minuta } & $\mathrm{y}$ & - & - & - & 1447 & 0.67 & 969.51 \\
\hline & q & - & - & - & 525 & 0.76 & 399.27 \\
\hline & qov & - & - & - & 1014 & 1.09 & 1105.09 \\
\hline \multirow[t]{3}{*}{ Moina micrura } & $\mathrm{y}$ & - & - & - & 0 & - & - \\
\hline & $q$ & - & - & - & 46 & - & - \\
\hline & qov & - & - & - & 9 & - & - \\
\hline Subtotal & & 14546 & - & 9794.23 & 8867 & - & 9264.95 \\
\hline Total & & 69323 & - & 14123.04 & 214069 & - & 11610.25 \\
\hline
\end{tabular}

total cyclopoids in Ponte Nova but only $1 \%$ in Guarapiranga. Thermocyclops decipiens, commonly associated with eutrophic conditions, represented $10 \%$ of total cyclopoids in Guarapiranga, but was not found in Ponte Nova.

In Ponte Nova, cladocerans were represented by a larger number of taxa and higher relative abundance, mainly during the cold season. Both reservoirs were dominated by Bosmina longirostris. Daphnia ambigua was well represented in Ponte Nova, while D. gessneri was more abundant in Guarapiranga.

The total zooplankton biomass was about 25-fold greater in Guarapiranga during the dry season (356.8 mgPS.m ${ }^{-3}$ ) than in Ponte Nova $\left(14.1 \mathrm{mgDW} \cdot \mathrm{m}^{-3}\right)$. During the rainy season the biomass was found to decrease in both reservoirs (80.7 and 11.5 mgDW.m ${ }^{-3}$, Guarapiranga and Ponte Nova, respectively, see Fig. 3).

Cyclopoids represented $66.2 \%$ of the total biomass in Guarapiranga during the dry season (Aug 2001), but its relative importance declined substantially in the rainy season (21.9\%). In Ponte Nova, cyclopoids occurred in low densities and biomass. Higher biomass contributions in Ponte Nova were due to cladocerans (73 and $80.6 \%$ ), which also contributed considerably in terms of biomass in Guarapiranga (19.5 and 46.7\%).

The calanoid biomass displayed a different pattern in each reservoir. During the dry season in Ponte Nova, this group represented $0.4 \%$ of the total densities and $8.5 \%$ of total biomass, but practically 
TABLE 3

Guarapiranga reservoir: numerical densities (ind.m $\left.{ }^{-3}\right)$, individual dry weights $(\mu \mathrm{gDW})$ and biomass $\left(\mu \mathrm{gDW} . \mathrm{m}^{-3}\right)$ of rotifers, cyclopoids, calanoids and cladocerans in Aug 2001 and Feb 2002 ( + , males; $\odot$, females; + ov, ovigerous females; y, young).

\begin{tabular}{|c|c|c|c|c|c|c|c|}
\hline \multirow{2}{*}{\multicolumn{2}{|c|}{ Rotifera }} & \multicolumn{3}{|c|}{ Aug 2001} & \multicolumn{3}{|c|}{ Feb 2002} \\
\hline & & ind. $\mathrm{m}^{-3}$ & $\mu \mathrm{gDW}$ & $\mu \mathrm{gDW} \cdot \mathrm{m}^{-3}$ & ind.m $\mathrm{m}^{-3}$ & $\mu \mathrm{gDW}$ & $\mu \mathrm{gDW} \cdot \mathrm{m}^{-3}$ \\
\hline Asplanchna sp. & & 59474 & 0.223 & 13274.52 & - & - & - \\
\hline Brachionus calyciflorus & & - & - & - & 3854 & 0.2332 & 898.75 \\
\hline B. havanaensis havanaensis & & - & - & - & 3854 & 0.0170 & 65.55 \\
\hline Collotheca ornata & & - & - & - & 30834 & 0.0194 & 599.68 \\
\hline Conochilus dossuarius & & - & - & - & 6745 & 0.0246 & 165.70 \\
\hline Conochilus unicornis & & 54763 & 0.062 & 3378.88 & 7227 & 0.0396 & 286.22 \\
\hline Filinia opoliensis & & - & - & - & 79013 & 0.0691 & 5461.90 \\
\hline Hexarthra intermedia & & - & - & - & 4818 & 0.0269 & 129.50 \\
\hline Kellicottia bostoniensis & & 32387 & 0.004 & 139.26 & 2409 & 0.0038 & 9.06 \\
\hline Keratella cochlearis & & 11188 & 0.001 & 15.66 & 4336 & 0.0011 & 4.78 \\
\hline K. cochlearis tecta & & - & - & - & 109847 & 0.0015 & 165.80 \\
\hline P. vulgaris var. longiremis & & 196086 & 0.033 & 6529.68 & 84312 & 0.0274 & 2310.72 \\
\hline Synchaeta oblonga & & 79494 & 0.249 & 19778.23 & - & - & - \\
\hline Trichocerca capucina & & 8833 & 0.152 & 1341.69 & - & - & - \\
\hline Trichocerca pusilla & & 2944 & 0.029 & 85.68 & 7709 & 0.0378 & 291.21 \\
\hline Subtotal & & 445169 & - & 44543.59 & 344958 & - & 10388.86 \\
\hline \multicolumn{8}{|l|}{ Copepoda Cyclopoida } \\
\hline Nauplii & & 141420 & 0.907 & 128253.31 & 30714 & 0.13 & 3992.79 \\
\hline Copepodids & & 27027 & 0.970 & 26211.90 & 22162 & 0.43 & 9529.70 \\
\hline \multirow[t]{3}{*}{ Themocyclops decipiens } & $\hat{\sigma}$ & 4819 & 1.031 & 496728 & 366 & 0.98 & 358.83 \\
\hline & q & 8276 & 5.050 & 41793.80 & 424 & 3.95 & 1674.68 \\
\hline & qov & 5657 & 5.705 & 32275.21 & 482 & 4.35 & 2095.76 \\
\hline \multirow[t]{3}{*}{ Thermocyclops inversus } & $\hat{0}$ & - & - & - & 39 & - & - \\
\hline & q & - & - & - & 39 & - & - \\
\hline & qov & - & - & - & 0 & - & - \\
\hline \multirow[t]{3}{*}{ Tropocyclops prasinus } & $\hat{0}$ & - & - & - & 77 & - & - \\
\hline & $q$ & - & - & - & 328 & - & - \\
\hline & qov & 629 & 2.096 & 1318.38 & 77 & - & - \\
\hline Subtotal & & 188771 & - & 236188.62 & 54707 & - & 17651.77 \\
\hline \multicolumn{8}{|l|}{ Copepoda Calanoida } \\
\hline Nauplii & & 113 & 5.388 & - & 2447 & 0.32 & 783.19 \\
\hline Copepodids & & 390 & 12.370 & 2101.13 & 1619 & 2.15 & 3480.41 \\
\hline \multirow[t]{3}{*}{ Notodiaptomus cf deitersi } & $\hat{0}$ & 77 & 15.260 & 946.93 & - & - & - \\
\hline & q & 82 & - & 1258.01 & - & - & - \\
\hline & qov & - & 9.600 & - & & & \\
\hline \multirow[t]{3}{*}{ Notodiaptomus iheringi } & $\hat{0}$ & 3 & 14404 & 28.26 & 790 & 6.41 & 5064.71 \\
\hline & q & 56 & 14.929 & 805.77 & 414 & 10.36 & 4292.51 \\
\hline & qov & 6 & 13.820 & 87.91 & 116 & 11.73 & 1356.32 \\
\hline \multirow[t]{3}{*}{ Notodiaptomus henseni } & $\hat{0}$ & 21 & 16.467 & 284.83 & 10 & - & - \\
\hline & q & 59 & - & 969.66 & 10 & - & - \\
\hline & qov & 15 & - & - & 29 & - & - \\
\hline Subtotal & & 821 & - & 6482.49 & 5435 & - & 14977.15 \\
\hline
\end{tabular}


TABLE 3

Continued...

\begin{tabular}{|c|c|c|c|c|c|c|c|}
\hline \multicolumn{2}{|l|}{ Cladocera } & & & & & & \\
\hline \multirow[t]{3}{*}{ Bosmina longirostris } & $\mathrm{y}$ & 10790 & 0.60 & 6509.97 & 58 & - & - \\
\hline & \begin{tabular}{|l} 
\\
+
\end{tabular} & 15713 & 1.41 & 22093.43 & 0 & - & - \\
\hline & qov & 1362 & 1.64 & 2237.57 & 39 & - & - \\
\hline \multirow[t]{3}{*}{ Bosminopsis deitersi } & $\mathrm{y}$ & 0 & - & - & - & - & - \\
\hline & 9 & 105 & - & - & - & - & - \\
\hline & qov & 105 & - & - & - & - & - \\
\hline \multirow[t]{3}{*}{ Ceriodaphnia cornuta cornuta } & $\mathrm{y}$ & - & - & - & 96 & - & - \\
\hline & 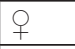 & - & - & - & 405 & 1.00 & 404.70 \\
\hline & qov & - & - & - & 251 & 1.20 & 300.63 \\
\hline \multirow[t]{3}{*}{ Ceriodaphnia silvestrii } & $\mathrm{y}$ & 1571 & 2.66 & 4177.43 & 2949 & 0.83 & 2447.27 \\
\hline & 9 & 4086 & 3.73 & 15236.83 & 1330 & 2.23 & 2965.29 \\
\hline & qov & 629 & 5.61 & 3530.26 & 1253 & 3.70 & 4634.77 \\
\hline \multirow[t]{3}{*}{ Daphnia ambigua } & $\mathrm{y}$ & 524 & 2.27 & 1187.31 & - & - & - \\
\hline & q & 524 & 3.19 & 1669.57 & - & - & - \\
\hline & qov & 629 & 4.09 & 2572.45 & - & - & - \\
\hline \multirow[t]{3}{*}{ Daphnia gessneri } & $\mathrm{y}$ & 314 & 3.36 & 1056.52 & 3006 & 2.51 & 7545.90 \\
\hline & 9 & 1152 & 5.35 & 6163.20 & 1021 & 5.93 & 6056.80 \\
\hline & qov & 210 & 15.06 & 3163.26 & 1619 & 8.26 & 13371.26 \\
\hline \multirow[t]{3}{*}{ Diaphanosoma birgei } & $\mathrm{y}$ & 210 & - & - & 19 & - & - \\
\hline & 웅 & 105 & - & - & 39 & - & - \\
\hline & qov & 0 & - & - & 39 & - & - \\
\hline \multirow[t]{3}{*}{ Moina minuta } & $\mathrm{y}$ & - & - & - & 0 & - & - \\
\hline & 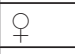 & - & - & - & 0 & - & - \\
\hline & qov & - & - & - & 19 & - & - \\
\hline Subtotal & & 38029 & - & 69597.80 & 12141 & - & 37726.63 \\
\hline Total & & 672790 & - & 356812.49 & 417356 & - & 80744.41 \\
\hline
\end{tabular}

disappeared in the rainy season. In Guarapiranga, the densities and biomass were higher during the rainy season, when they ranked second in total biomass, after cladocerans (Fig. 4).

In Guarapiranga, cyclopoid nauplii, adult and ovigerous females of Thermocyclops decipiens, adult females of Bosmina longirostris and Synchaeta oblonga contributed the most to the biomass during the dry cold season while, in the warm rainy one, copepodids of Cyclopoida, males and females of Notodiaptomus iheringi, young, adult and ovigerous females of Daphnia gessneri, and Filinia opoliensis exhibited high biomass values.
Young and adult females of Bosmina longirostris, adult and ovigerous females of Ceriodaphnia silvestrii, Ceriodaphnia cornuta rigaudi, and Polyarthra vulgaris were the major contributors in Ponte Nova, during the dry and cold season. During the rainy season, cladocerans were the only contributors, mainly young and ovigerous females of Bosmina longirostris, young of Ceriodaphnia silvstrii, ovigerous females of Daphnia ambigua, and young and ovigerous females of Moina minuta.

\section{DISCUSSION}

Variables such as chlorophyll and nutrients, which reflect the trophic state, were higher in 


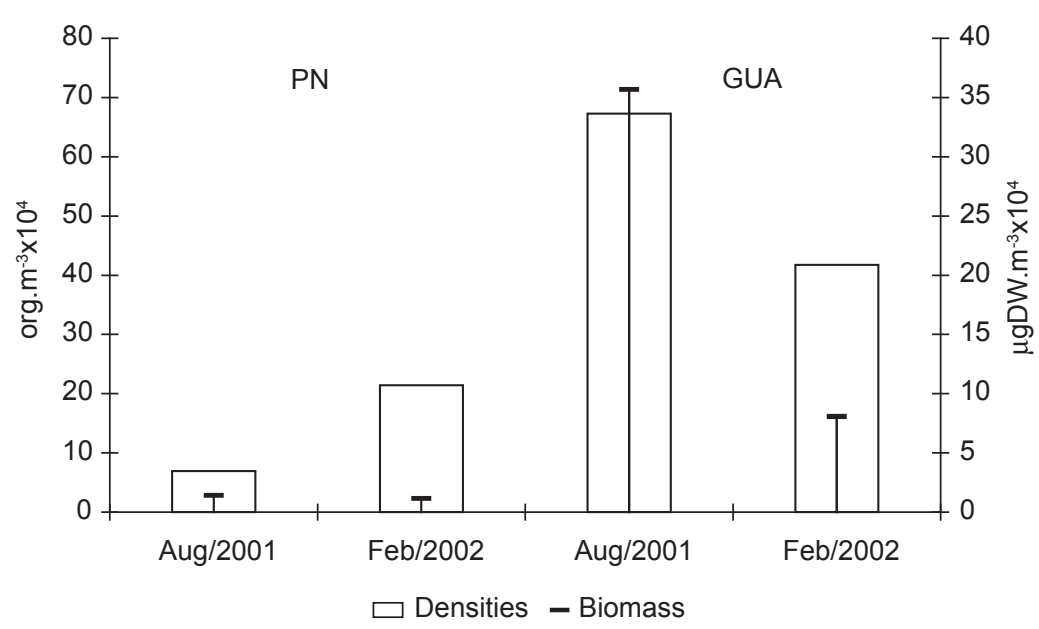

Fig. 3 - Zooplankton densities (number of organisms.m ${ }^{-3}$ ) and biomass $\left(\mu \mathrm{gDW} . \mathrm{m}^{-3}\right)$ in Ponte Nova (PN) and Guarapiranga (GUA) reservoirs, during the cold and dry (August 2001) and warm and rainy (February 2002) periods.
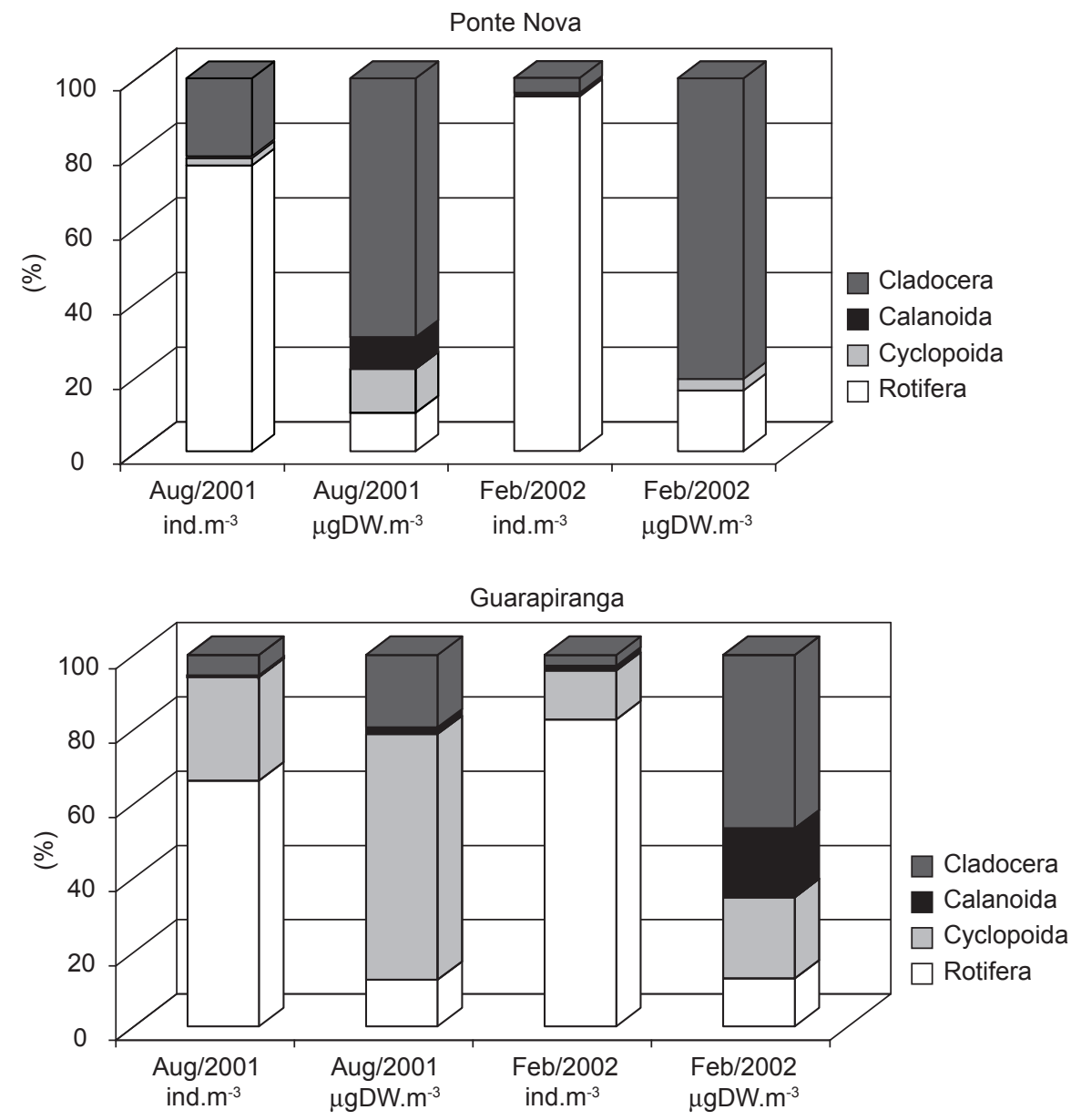

Fig. 4 - Relative contribution and numerical densities (ind. $\mathrm{m}^{-3}$ ) and biomass $\left(\mu \mathrm{gDW} . \mathrm{m}^{-3}\right)$ of rotifers, cyclopoids, calanoids and cladocerans in Ponte Nova and Guarapiranga reservoirs, in August 2001 and February 2002. 
Guarapiranga reservoir. Along two decades of studies, this reservoir exhibited an intense process of eutrophication.

Both reservoirs also showed an increase in the chlorophyll concentration; a comparison with data obtained in the dry and rainy seasons by Maier \& Takino (1985b) at the same sites shows an increase from 3.6 and $12.9 \mu \mathrm{g} . \mathrm{L}^{-1}$ to 5.9 and $5.3 \mu \mathrm{g} . \mathrm{L}^{-1}$ in Ponte Nova, and from 4.4 and $9.0 \mu \mathrm{g} . \mathrm{L}^{-1}$ to 31.2 and $25.9 \mu \mathrm{g} . \mathrm{L}^{-1}$ in Guarapiranga.

In this study, differences in physical and chemical variables associated with the dry and rainy seasons were observed at Guarapiranga, where nitrogen and phosphorus compounds and pigments were lower during the warm rainy season due to the dilution of superficial water.

Water bodies showing a trophic state index below 44 are oligotrophic, from 44 to 54 they are mesotrophic, and above 54 they are eutrophic. In the present study, the MTSI of Ponte Nova (42) and Guarapiranga (59) reflected, respectively, oligotrophic and eutrophic environments. Caleffi et al. (1994) obtained a TSI (Carlson, 1977) of 51 for Guarapiranga in previous studies; however, the TSI found in this study was the same as the MTSI, i.e., 59. The values found in the present study reflect the intensified eutrophication process as well as the input of the waters of Billings reservoir, transferred to Guarapiranga through the recent reversion of the Taquacetuba branch in August 2000.

As expected, in this study the two reservoirs were found to be numerically dominated by rotifers, a predominance that various authors have also found in other reservoirs in the state of São Paulo. Rotifers represented $78 \%$ of the total zooplankton in the Broa reservoir, which was oligotrophic at that time (Matsumura-Tundisi \& Tundisi, 1976), and also predominated in 16 out of 17 reservoirs studied by Sendacz et al. (1985), and in the eutrophic Barra Bonita reservoir (Wisniewski, 1998).

As observed in Guarapiranga and in other eutrophic reservoirs (Domingos, 1993; Caleffi, 1994; 2000; Wisniewski, 1998; Piva-Bertoletti, 2001), zooplankton densities are usually lower during the warm rainy season, following a decrease of nutrients resulting from the dilution of superficial water. The opposite occurs in oligotrophic environments (Melão, 1997), where an increase in primary production is expected in the rainy season pursuant to the input of nutrients.

Ptygura sp, Polyarthra $s p$ and Collotheca $s p$ predominated in Ponte Nova both in 1979 (Sendacz et al., 1985) and in this study, as well in other oligotrophic reservoirs of the Alto Tietê basin, such as Cabuçu, Pedro Beicht and Taiaçupeba (Arcifa, 1984). Thus, the structure of the rotifer community has not changed over the years, following the trophic conditions of Ponte Nova. Guarapiranga showed the opposite pattern: changes in the zooplankton community relating both to the relative abundance of groups and to predominant species occurred in response to eutrophication.

Cyclopoids and calanoids were poorly represented in Ponte Nova while, in Guarapiranga, young stages represented $25 \%$ of the total zooplankton. Declining calanoid densities in Guarapiranga were probably due to lower water temperatures recorded during the cold season. Notodiaptomus iheringi was important due to its ability to replace other calanoid species in eutrophic waters (Coelho-Botelho et al., 1999; Rietzler et al., 2002).

Studies involving estimations of the dry weight and biomass of zooplankton organisms are rare. A comparative approach is difficult due to the use of different methodologies. Matsumura-Tundisi et al. (1989) and Melão (1997) estimated dry weights of microcrustaceans in the Broa reservoir (SP) and in the Lagoa Dourada reservoir (SP) using a microbalance. Wisniewski (1998) obtained data from the literature for the Barra Bonita reservoir. Also, comparisons were not always possible due to differences in the composition of species.

Some species recorded in this study were also found in the oligotrophic Lagoa Dourada reservoir (Melão, 1997), such as Tropocyclops prasinus and Ceriodaphnia cornuta, found in both reservoirs.

In Guarapiranga, Bosmina longirostris showed high dry weights during the dry season similar to those obtained at Barra Bonita by Wisniewski (1998), while the dry weights of $B$. longirostris were low in the oligotrophic Ponte Nova reservoir.

The dry weight of organisms of the same size may change according to the life cycle, nutritional state and reproductive conditions (Rocha, 1983), and the trophic conditions of the water (Andrew \& Fitzsimons, 1992). Differences in the dry weight 
estimates of this study were attributed to both seasonal factors and each reservoir's trophic state, reflecting the nutritional state of the organisms.

The individual biomass should not be calculated from weight-length relationships found in the literature, since these relationships change according to temperature, food quality and availability, and genotype (Vijverberg, 1989).

The dry weight of Ceriodaphnia cornuta rigaudi, recorded in Ponte Nova during the dry and cold seasons, was higher than the dry weight of Ceriodaphnia cornuta cornuta, recorded in Guarapiranga in the warm rainy season and by Melão (1997) in Lagoa Dourada reservoir, but lay within the range established by Dumont $e t$ al. (1975).

As for calanoid copepods, the dry weight of Argyrodiaptomus furcatus was estimated earlier by Matsumura-Tundisi et al. (1989); however, this study adds an estimate of the dry weight of Odontodiaptomus paulistanus and of three Notodiaptomus species.

Although rotifers predominated numerically in both reservoirs and seasons, in terms of biomass in the cold dry season, cyclopoid copepods contributed more in Guarapiranga and cladocerans in Ponte Nova. In the warm rainy season, cladocerans represented the highest biomass in both reservoirs.

A comparison with oligotrophic data (Melão, 1997) reveals that Ponte Nova followed the same pattern, i.e., a higher contribution of cladocerans occurred in both seasons. The changes in biomass patterns in Guarapiranga were probably due to instable physical and chemical conditions.

The total zooplankton biomass in Ponte Nova (14.1 mgDW.m $\left.{ }^{-3}\right)$ and Guarapiranga (354.6 $\mathrm{mgDW} \cdot \mathrm{m}^{-3}$ ) in the cold dry season was higher than that reported by Melão (op.cit.) (4.6 and $5.9 \mathrm{mgDW} . \mathrm{m}^{-3}$ ) and Wisniewski (op.cit.) (50.0 to $290.1 \mathrm{mgDW} \cdot \mathrm{m}^{-3}$, with a mean value of $\left.88.5 \mathrm{mgDW} \cdot \mathrm{m}^{-3}\right)$.

These levels of biomass lay within the limits of 3 to $355 \mathrm{mgDW} . \mathrm{m}^{-3}$ reported for African lakes and reservoirs by Allanson et al. (1990, apud Melão, 1999). The biomass values obtained for Guarapiranga were close to the upper levels in African aquatic systems.

The zooplankton biomass was found to decrease in the warm rainy season mainly in the
Guarapiranga reservoir. During this season, both reservoirs showed lower values of total pigments and total suspended solids. The same trend was observed in Barra Bonita reservoir by Wisniewski (op.cit.), although Melão (op.cit.) recorded an increase of biomass values for the Lagoa Dourada reservoir.

The extent of seasonal variation can be characterized by the ratio of maximum to minimum biomass; ratios $>10$ appear to be typical of zooplankton communities in the temperate zone (Saunders \& Lewis, 1988). A ratio of $<10$, detected in this study for both reservoirs, has also been found in other large tropical lakes, e.g., lakes Chad (Saint-Jean, 1983), George (Burgis, 1974) and Lanao (Lewis, 1979).

The total zooplankton biomass estimated for Ponte Nova corresponds to other environments with similar trophic conditions, such as the Carioca Lake, Doce River and Lobo reservoir, for which values of 10.9 and 11 to $16 \mathrm{mgDW} . \mathrm{m}^{-3}$ were estimated, respectively, by Matsumura-Tundisi \& Tundisi (1986) and Matsumura-Tundisi et al. (1989).

The zooplankton biomass of Guarapiranga reservoir was much higher when compared with other eutrophic environments such as the Amarela Lake, Doce river (173.9 mgDW.m³) (MatsumuraTundisi \& Tundisi, op.cit.) and Barra Bonita reservoir (Wisniewski, 1998).

The mean biomass of cyclopoid and calanoid copepods at Barra Bonita reservoir was 50.5 mgDW.m ${ }^{-3}$ (Wisniewski, op.cit). The cyclopoid copepods biomass in Guarapiranga was $236 \mathrm{mgDW} \cdot \mathrm{m}^{-3}$ in the cold dry season, and $17.6 \mathrm{mgDW} . \mathrm{m}^{-3}$ in the warm rainy one.

With regard to oligotrophic environments, the rotifer biomass values reported by Melão (1997) $\left(0.9 \mathrm{mgDW} \cdot \mathrm{m}^{-3}\right)$ were lower than those estimated for Ponte Nova $\left(1.5 \mathrm{mgDW} . \mathrm{m}^{-3}\right)$. As for eutrophic environments, the rotifer biomass values of Guarapiranga reservoir were higher (44.5 mgDW. $\mathrm{m}^{-3}$ ) than those estimated by Wisniewski (op.cit.) (4.6 mgDW. $\left.\mathrm{m}^{-3}\right)$.

The data reported here suggest different patterns of numerical densities and levels of biomass associated with trophic conditions. The biomass values for Ponte Nova were similar in the two seasons, while numerical densities increased in the rainy season. Higher numerical densities 
and biomass were observed in Guarapiranga in the dry season, when physical and chemical variables reflected highly eutrophic conditions.

Acknowledgments - This study was supported by FAPESP (Brazil) under contract number 01/02593-1.

\section{REFERENCES}

ANDREW, T. E. \& FITZSIMONS, A. G., 1992, Seasonality, population dynamics and production of planktonic rotifers in Lough Neagh, Northern Ireland. Hydrobiologia, 246: 147-164.

ARCIFA, M. S., 1984, Zooplankton composition of ten reservoirs in southern Brazil. Hydrobiologia, 113: $137-145$.

BOTTRELL, H. H., DUNCAN, A., GLIWICZ, Z. M., GRYGIEREK, E., HERZIG, A., HILLBRICHT-ILKOSKA, A., KURAZAWA, H., LARSSON, P. \& WEGLENSKA, T., 1976, A review of some problems in zooplankton production studies. Norw. J. Zool., 24: 12-456.

BURGIS, M. J., 1974, Revised estimates for the biomass and production of zooplankton in Lake George, Uganda. Freshwater Biology, 4: 535-541.

CALEFFI, S. A., 1994, represa de Guarapiranga: estudo da comunidade zooplanctônica e aspectos da eutrofização. Dissertação de Mestrado - FSP/USP, São Paulo.

CALEFFI, S., 2000, Estudo da comunidade zooplanctônica da represa de Guarapinga: Aspectos ecológicos e qualidade ambiental, 1991/92, Tese (Doutorado) - FSP/USP, São Paulo.

CALEFFI, S., ZANARDI, E. \& BEYRUTH, Z., 1994, Trophic state of Guarapiranga reservoir in 1991/92. Verh. Internat. Verein Limnol., 25(3): 1306-1310.

CARLSON, R. E., 1977, A trophic state index for lakes. Limnol. Oceanogr., 22(2): 361-9.

COELHO-BOTELHO, M. J., CABIANCA, M. A. A. \& SENDACZ, S., 1999, Alterações na composição da comunidade zooplanctônica em represas do Alto e Médio Tietê, Estado de São Paulo. CONGRESSO BRASILEIRO DE LIMNOLOGIA. 7. Anais. Florianópolis, 1999, 18 a 22/07/1999. 194p.

CULVER, D. A., BOUCHERLE, M. M., BEAN, D. J. \& FLETCHER, J. W., 1985, Biomass of freshwater crustacean zooplankton from length-weigth regressions. Can. J. Fish. Aquat. Sci., 42: 1380-1390.

DOMINGOS, M. D., 1993, Heterogeneidade espacial (horizontal) da represa do Guarapiranga (São Paulo) e a distribuição da comunidade zooplanctônica. Dissertação (Mestrado) - EESC/USP, São Paulo.

DUMONT, H. J., VAN DE VELDE, I. \& DUMONT, S., 1975, The dry weight estimate of biomass in a selection of Cladocera, Copepoda and Rotifera from the plankton, periphyton and benthos of continental waters. Oecologia, 19: 75-97.

ESTEVES, K. E. \& SENDACZ, S., 1988, Relações entre a biomassa do zooplâncton e o estado trófico de reservatório do Estado de São Paulo. Acta. Limnol. Brasil., 2: 587-604.
HART, R. C., 1987, Population dynamics and production of five crustacean zooplankters in a subtropical reservoir during years of contrasting turbidity. Freshwater Biology, 18: 287-318.

LEWIS, W. M., 1979, Zooplankton community analysis: studies on a tropical system. New York, Springer-Verlag, 163p.

MAIER, M. H. \& Takino, M., 1985a, Limnologia de reservatórios do sudeste do Estado de São Paulo, Brasil. III. Qualidade da água. B. Inst. Pesca, 12(1): 45-73.

MAIER, M. H. \& TAKINO, M., 1985b, Limnologia de reservatórios do sudeste do Estado de São Paulo, Brasil. IV. Nutrientes e clorofila a. B. Inst. Pesca, 12(1): 75-102.

MARKER, A. F. H., NUSCH H., RAI, H. \& RIEMANN, B., 1980, The measurement of photosynthetic pigments in freshwaters and standardization of methods: conclusion and recommendations. Arch. Hydrobiol. Beih., 14: 91-106.

MATSUMURA-TUNDISI, T. \& TUNDISI, J. G., 1976, Plankton studies in a lacustrine environment. I. Preliminary data on zooplankton ecology of Broa reservoir. Oecologia, 25: 265-270.

MATSUMURA-TUNDISI, T. \& TUNDISI, J. G., 1986, Biomass and zooplankton community structure of three lakes of River Doce Valley (Minas Gerais, Brazil). An. Fifth Japan-Brazil Symposium on Science and Technology. Tokyo.

MATSUMURA-TUNDISI, T., RIETZLER, A. C. \& TUNDISI, J. G., 1989, Biomass (dry weight and carbon content) of plankton Crustacea from Broa reservoir (São Carlos, SP, Brazil) and its fluctuation across one year. Hydrobiologia, 179: 229-236.

MELÃO, M. G. G., 1997, A comunidade planctônica (fitoplâncton e zooplâncton) e produtividade secundária do zooplâncton de um reservatório oligotrófico. Tese (Doutorado) - UFSCar, São Carlos, SP. 151p.

MELÃO, M. G. G., 1999, A produtividade secundária do zooplâncton: métodos, implicações e um estudo na Lagoa Dourada. pp. 151-183. In: R. Henry (ed). Ecologia de reservatórios: estrutura, função, aspectos sociais. Botucatu, SP: FUNDIBIO: FAPESP.

MELÃO, M. G. G. \& ROCHA, O., 2000, Productivity of zooplankton in a tropical oligotrophic reservoir over short periods of time. Verh. Internat. Verein. Limnol., 27: 2879-2887.

PIVA-BERTOLETTI, S. A. E., 2001, Zooplâncton dos lagos do Parque Estadual das Fontes do Ipiranga $(S P)$ e relações entre espécies zooplanctônicas e estado trófico em corpos d'água do Estado de São Paulo. Tese (Doutorado) - FSP/ USP. 253p.

RIETZLER, A. C., MATSUMURA-TUNDISI, T. \& TUNDISI, J. G., 2002, Life cycle, feeding and adaptive strategy implications on the co-occurrence of Argyrodiaptomus furcatus and Notodiaptomus iheringi in Lobo-Broa reservoir (Brazil-SP). Braz. J. Biol., 62(1): 93-105.

ROCHA, O., 1983, The influence of food-temperature combinations on the duration of development, body size, growth and fecundity of Daphnia species. Tese (Doutorado) - Royal Holloway College, London. 337p. 
RUTTNER-KOLISKO, A., 1977, Suggestions for biomass calculations of plankton rotifers. Arch. Hydrobiol. Beih. Ergebn. Limnol., 8: 71-76.

SAINT-JEAN, L., 1983, The zooplankton, pp. 199-232. In: J. P. Carmouze, J. R. Durand \& C. Leveque (eds), Lake Chad, Ecology and Productivity of a Shallow Tropical Ecosystem. Dr W. Junk, The Hague.

SAUNDERS, J. F. \& LEWIS, W. M., 1988, Composition and seasonality of the zooplankton community of Lake Valencia, Venezuela. Journal of Plankton Research, 10(5): 957-985.

SENDACZ, S. \& KUBO, E., 1982, Copepoda (Calanoida e Cyclopoida) de reservatórios do Estado de São Paulo. B. Inst. Pesca, 9: 51-89.

SENDACZ, S. \& KUBO, E., 1999, Zooplâncton de reservatórios do Alto Tietê, Estado de São Paulo, pp. 509-530. In: R. Henry (ed), Ecologia de reservatórios: estrutura, função, aspectos sociais. Botucatu, SP: FUNDIBIO: FAPESP.

SENDACZ, S., KUBO, E. \& CESTAROLLI, M. A., 1985, Limnologia de reservatórios do sudeste do Estado de São Paulo, Brasil. VIII Zooplâncton. B. Inst. Pesca, 12(1): 187-2079.

TOlEDO Jr, A. P., TALARICO, M., CHINEZ, S. J. \& AGUDO, E. G., 1983, A aplicação de modelos simplificados para a avaliação de processo de eutrofização em lagos e resevatórios tropicais. Camboriú - SC. pp. 1-34. In: CONGRESSO BRASILEIRO DE ENGENHARIA SANITÁRIA E AMBIENTAL. 7, Anais.

VALDERRANA, J. C., 1981, The simultaneous analysis of nitrogen and total phosphorus in natural waters. Marine Chemistry, 10: 109-122.

VÁSQUEZ, E. \& REY, J., 1992, Composition, abundance and biomass of zooplankton in Orinoco floodpalin lakes, Venezuela. Annls Limnol., 28(1): 3-18.

VIJVERBERG, J., 1989, Culture techniques for studies on the growth, development and reproduction of copepods and cladocerans under laboratory and in situ conditions: a review. Freshwater Biology, 21: 317-373.

WETZEL, R. G. \& LIKENS, G. E., 1991, Limnological Analyses. $2^{\text {th }}$ ed. New York: Springer-Verlag.

WISNIEWSKI, M. J. S., 1998, Distribuição espacial e produção secundária da comunidade zoopalnctônica do reservatório de Barra Bonita, SP. Tese (Doutorado)-UFSCar, São Carlos - SP. 140p.

XAVIER, M. B., MONTEIRO-JÚNIOR, A. J. \& FUJIARA, L. P., 1985, Limnologia de reservatórios do sudeste do Estado de São Paulo, Brasil. VII. Fitoplâncton. B. Inst. Pesca, São Paulo, 12(1): 145-186. 